\title{
Entrepreneurship the mediating role of finance and entrepreneurial education for small farmers in developing countries: Evidence from India
}

\begin{abstract}
Purpose: This paper investigates the mediating role of access to finance and entrepreneurial education for Small and Marginal Farmers (SMFs) in the Indian northern state of Punjab. Furthermore, it examines the inter-mediatory role of entrepreneurs and the access to finance in the promotion of innovation, development and consequently poverty alleviation.

Design / methodology / approach: To gain a deeper insight, we used a purposive sampling technique, involving in-depth, face-to-face interviews based on a semi-structured questionnaire amongst 185 farmers from the state of the Punjab in India. The combination of open ended and dichotomous questions amenable to the Likert scale, captured responses and the transcribed questionnaires were thematically analysed.

Findings: Using the analysis of the quantitative and qualitative responses, we explain the cause and consequences of the finance gap and the impact of poverty on household income and the debt levels of SMFs. The findings suggest the expanding pool of SMFs is due to land ownership fragmentation that disenfranchises SMFs from accessing adequate finance thus limiting their ability to adapt to technological innovations, and therefore limiting their productivity and growth. This essentially limits their ability to transform their economic and social wellbeing. The findings from the data analysis suggest a lack of access to finance negatively impacts on SMFs' ability to use innovative practices, technologies and productivity. This adversely affects income level, access to education and social goods to propel them out of poverty. The findings advocate that government policy should focus on land reforms, which provide adequate access to finance to enable the adaption of technology and an access to markets to empower marginal farmers.
\end{abstract}

Research implications / limitations: Land fragmentation resulting with population growth in emerging economies continuously expands SMFs. To improve efficiency, productivity and entrepreneurial traits amongst SMFs, it is a pre-requisite to have an agile economy. However, in emerging economies such as India, the responses of 185 farmers suggest, a bespoke policy to promote the interest of SMFs through enabling them access to finance, technologies, training and education, continues to prove elusive. This novel empirical research provides evidence that demands that policy makers, commercial institutions and donors need to respond to the needs of SMFs to ensure food security and an optimal utilization of farmland. The limitation of this research is that the sample is from one country, which limits its generalization. The findings of this study could be enhanced by conducting comparative studies in other regions or economies.

Originality / value: This empirical study examined the barriers to enterprise for SMFs in the Indian Punjab; it examined the causes and consequences and the implications for food security for India. The findings of this study highlight the importance of developing the entrepreneurial capabilities of SMFs through effective education, training and above all through an adequate access to finance to enable them to adapt their technology. Furthermore, the findings make a case as to why SMFs are an integral part of the food chain and why it is necessary to enhance their efficiency, productivity and their access to finance.

Paper type: Research paper 


\section{Introduction}

The importance of entrepreneurship amongst the agricultural sector has been recognised as an essential trait that promotes cohesive and progressive economic structures for progressive economies (Matlay, et al., 2012). An entrepreneurship strategy amongst farmers has evolved to 'exploit the changes in the strategic environment' (Alsos and Carter, 2006; Igwe et al., 2020; Zhou et al., 2019), either as a strategy to develop business or to secure economic survival to continue to retain an agro-based livelihood (Fitz-Koch et al., 2018).

Therefore, it is not a surprise that the agricultural sector has gained the attention of academics, policy makers and governments around the world to develop interventionist policies and strategies to promote entrepreneurship initiatives amongst farmers. One such policy is to address the financial needs of farmers who have smallholdings. Adequate, timely and optimal levels of finance are important for the efficacy of the agricultural sector as the activities associated with the sector are resource intensive and seasonal (Wongnaa and Awunyo-Vitor, 2018). Small Marginal Farmers (SMFs) are observed to encounter similar constraints to Small Marginal Enterprises (SMEs). The agricultural sector at large, and SMFs in particular, have implications for poverty alleviation and food security for the rural economy that contains a high concentration of the population and a large amount of agricultural activity. Improved access to finance enables SMFs to employ advanced technologies that enhance agricultural productivity that leads to poverty reduction and food security amongst farmers (Bashir et al., 2010). Studies by Awunyo-Vitor et al. (2018) for Ghana and ljaz et al. (2019) for Pakistan, supported the view that improved access to finance influenced the productivity of yam and rice in these respective countries. Similar findings are supported by several studies, (Asante et al., 2014; Coelli and Battese, 1996; Martey et al., 2015) that adequate finance led to an increased productivity and efficiency amongst farmers. The successive findings support the assertion that adequate access to finance improves the welfare and efficiency of the agricultural sector; hence, the success or failure of the sector has important policy implications.

Entrepreneurship, innovation and productivity amongst farmers, are dependent on farm size, land quality, labour and capital (Cele and Wale, 2020; Igwe et al., 2020). 
The resource based view is that the owner/manager's experience, network, skills and the land size of farmers affect their access to external finance, information and knowledge that contributes towards the success of the farmers' economic and strategic growth (Barbieri and Mshenga, 2008; Phelan and Sharpley, 2012). Entrepreneurship amongst the agricultural sector has gained importance as the demand for land use grows and in developing economies, land fragmentation accelerates due to population growth. However, entrepreneurship studies consider the agricultural sector from the lens of efficiency - how to innovate and economically organise the land holdings to generate opportunities (Bryden and Geisler, 2007). The agricultural sector has remained a focal point of interest for national and international governments for decades due to its importance for food security and environmental implications. This suggests that for an understanding of the agricultural sector, there is a need to contextualise the sector (Zahra, 2007; Fitz-Koch et al., 2018). Through contextualising the agricultural sector, discernment of its dimension will yield a deeper insight as this provides an 'historical, temporal, spatial, institutional and social context' with which to understand entrepreneurship (Welter (2011). Within this context, we use Fitz-Koch et al.'s (2018) logic to examine the agricultural sector, in particular, its subset of Small and Marginal Framers (SMFs).

\section{Literature review}

The agricultural sector, for most economies, is large and the largest employer (employing one billion people) and it contributes 3\% to the GDP (Bruinsma, 2017). According to the World Bank (2004: 2016b) the agricultural sector is considered as the backbone of the developing countries especially Indian economy as it is the largest employer and caters for masses. The entrepreneurial initiatives of farmers worldwide and in India, have led to a restructuring of the agricultural sector that has enabled larger farmers to gain control through vertical integration. However, according to researchers such as Alsos et al., (2011), Hendrickson et al., (2017) and Moreno-Pe'rez et al., (2015) smaller family owned farms continue to survive at large. Given the close attachment of Indian farmers with land and tradition where land ownership tends to be passed on to next generation; the agricultural sector has remained a way of life rather than a business in India (Bharti and Sagar, 2020). Despite the significant increase in the urban population in India, 72.2 per cent of the 
population still lives in rural India (Bharti and Sagar, 2020; Patel et al., 2004; Pol, 2016). However, in comparison with the West, Indian farmers' land holding size continued to decline as land ownership is divided within families leading to a decline in the economies of scale. Whereas landownership in developed economies experienced a concentration of ownership through the acquisition of small farmers landholdings enabling the larger holdings to innovate and to employ advanced technology. Such structures enable the agricultural sector to align itself with the supply chain relationship to rationalise the interconnectedness between supplier and buyer (McElwee \& Bosworth, 2010). In contrast, within many developing economies, 90 percent of total landholdings are small, marginal and non-economical due to increasing cultivation costs (Dey, 2018; Meher, 2015). This suggests that agricultural entrepreneurship is a function of the agricultural environment, farmers' competencies, access to finance that has been found to be often associated with older, larger size farms (Bateman and Ray, 1994). Barbiereri et al. (2008) suggest that farmers equally use a pecking order theory to access external finance and are reluctant to access external finance due to the perceived risk of losing control (Alsos et al., 2014 and Hansson et al., 2012). Hence, family composition, agricultural land size and the age of farms are contributory factors for the success of entrepreneurial strategies to alleviate poverty amongst SMFs.

The unit of analysis in this paper is the individual small and medium sized farmer, based in the Indian Punjab. The region hosts $78 \%$ of the country's farmers and $33 \%$ of the total cultivated land; the sector's contribution is larger than that of the medium and large sized firms (Singh et al., 2002). Indian SMFs are embedded within the family's social and economic structures that inform their practices; they tend to have an ambiguous understanding and application of entrepreneurial strategies for growth though they recognise enterprise has a positive effect on household income. Hinrichs, Gillespie and Feenstra (2004) capture the essence of Indian SMFs in that they are 'social institutions' and more than an enterprise as such. Therefore, size is not of the essence to many, though Sen (1964) reported an inverse relationship between farm size and productivity. Within India, SMFs are the main contributors to agricultural production but their efficiency and productivity remain low due to lower 
learning processes, the under use of technology, poorer managerial skills, and entrepreneurial competencies and most importantly lack of access to finance.

The finance gap is persistent amongst small enterprises and is often associated with a lack of collateral and the perceived non-financial viability of lending to farmers. Due to social taboos and the difficulty to secure sales of land and communial issues, banks tend to avoid taking land as a collateral. Therefore, a lack of access to external finance for SMFs forces them to access credit through informal sources such as families and traditional moneylenders. Informal, non-regulated moneylenders give rise to adverse outcomes in terms of high cost, social pressure and operating on harsh terms and conditions. Financial deepening and access to finance is a precursor to entrepreneurial initiatives that promote economic growth. This suggests that there is a need for an institutional framework that connects itself to local and regional policies for promoting enterprise amongst SMFs as advocated by Hoff \& Stiglitz (1997); they suggested that policy intervention in the rural credit markets of developing countries has largely failed to improve access to formal credit to SMFs. The subsidised and directed credit provisions have mostly benefited larger farms. The consequence of finance constraint has led SMFs to use traditional methods of cultivation leading to low productivity because they are unable to make heavy investments for better irrigation facilities, seeds, fertilizers and machinery. These findings are supported by (Chavan and Sivamurugan, 2017; Dey, 2018; Kashanahs, 2001; Kohli and Singh, 2005; Murgai et al., 2001; Olubiyo, 2003) access to finance has limited growth amongst SMFs, findings supported by the World Bank (2001). Access to financial products and services is a key ingredient to promote entrepreneurship amongst SMFs and safeguard them against non-regulated informal financiers. More than half of all credit providers to SMFs are informal lenders (Rajiv, et al., 2012); they charge high interest rates and use unethical tactics to exploit SMFs and this give rise to poor mental health and the impaired well-being of farmers and has led to a high incidence of suicide amongst SMFs.

This paper reports the findings of an empirical investigation of the Punjab agricultural region that produces one per cent of rice, two per cent of wheat and two percent of cotton in terms of the total world production (GoP, 2010; Srivastava et al., 2017). However, this incremental yield is associated with rising high marginal costs. 
(Ghuman, 2001; Jelsma, et al., 2019; Singh et al., 2012). The ever-rising cost of cultivation and a declining net return has resulted in the heavy indebtedness of farmers (Ghuman, 2008) that demands a higher investment and entrepreneurial innovation, which requires access to finance to enhance productivity and mitigate the effects of poverty. The paper analyses the pertinent questions such as what are the barriers to enterprise amongst SMFs, what is the extent of poverty among farming households and what are the possible strategies to improve access to finance and to promote an entrepreneurial mind-set to alleviate poverty among SMFs? Thus, the factors influencing farmers' access to financial services and the effect of credit on productivity and poverty are investigated by examining the following areas:

- The effect of credit on farm productivity and the level of poverty amongst farmers

- Relationship between entrepreneurship and pervasive social-cultural and economic factors

- Empowering characteristics of agricultural entrepreneurship.

Entrepreneurship, access to finance and poverty alleviation amongst farmers

Entrepreneurship within the agricultural sector has been reported to reduce poverty (World Bank, 2008) this suggests that there is a case for providing an enabling environment for SMFs to engage with entrepreneurial-based activities. Bee (2007) suggests that when developing the entrepreneurial attributes of farmers, access to finance is a prerequisite, as the sector requires the adoption of agricultural technology. Access to finance for SMFs is contingent on collateral and an information set that enables lenders to assess default risk through screening and then estimating the probability of default and monitoring. However, SMFs do not have the capacity, financial knowledge or the viable collateral to secure loans to purchase agricultural technologies to boost productivity, reduce the costs of production and negate the outcomes associated with poverty.

Poverty is a relational condition that arises from the operation of existing social relations and the adverse terms of inclusion in socio-economic systems (Mosse, 
2007; Williams et al., 2012). Tilly's interactional theory of inequality suggests that asymmetric relations across unequal and socially recognised categories, generates poverty when value-producing resources are exclusively held by an in-group (opportunity hoarding), or when that group manages to extract value from the efforts of others (exploitation) (Tilly, 2007; Williams et al, 2012). In terms of SMFs, the 'hoarders' are informal lenders who use economic power to exploit small farmers. Within this context, social identity matters as it influences access to resources, leaving the control of resources for the dominant groups (Jelsma et al., 2019; HarrisWhite, 2005:2006; Hickey and du Toit, 2013; Mosse, 2007). Such an environment leads to social, economic and financial exclusion amongst smaller farmers that limits their entrepreneurial activities. Concurrently, several studies (Krishna, 2004: 2006; Krishna et al., 2005; Singh, 2010; Vatta et al., 2008) related to India, have highlighted that these three factors: health expenses, high indebtedness from informal sources and extravagant social and customary expenses, mainly cause Indian households to descend into poverty.

\section{Poverty Alleviation Programmes in India}

Poverty is a social stigma that has received considerable attention in developing economies. Governments and associated agencies increasingly sought to alleviate poverty using multiple approaches. Kumari and Singh (2009) suggested efforts are being made to identify the critical factors that mitigate poverty at large, specifically in India. Since the 1970s and progressively in the 2018s developing economies have used multidimensional techniques to promote growth and to negate the effect of poverty (Diao et al., 2019; Wang and Wang 2020). Consequently, progressive governments in India have put in place poverty alleviation programmes to support rural areas through the Integrated Rural Development Programme (IRDP) started in 1970. The success of IRDP has meant that by the 1980s, the scheme was extended to schedule castes and tribes, women and rural artisans. To address the wage unemployment (unemployment during the lean agricultural season as well as during the drought and floods), the National Social Assistance Programme (NSAP) in 1995 was introduced (Ansari and Akhtar, 2012; Ashraf, 2020; Das and Patnaik, 2020). Despite all of the concerted efforts by the government, at the end of $20^{\text {th }}$ century, 260 
million people in India were living below the poverty line (Ansari and Akhtar, 2012; Manzoor, 2019). According to the World Bank (2020), approximately $80 \%$ of the Indian population lives on less than $\$ 2.17$ per day. The Tendulkar Committee reported that $37 \%$ of people in India live below the poverty line. According to the report one in three Indians lives below the poverty line (Singh et al., 2012) and the majority of them, (75\%) live in rural India (Ansari and Akhtar, 2012; Ashraf, 2020; Manzoor, 2019). Hence, for this study, following the World Bank's methodology (World Bank, 2016a: 2019) of $\$ 1.90$ a day is used to estimate the population living below the poverty rate (BPR) and Rangarajan (2014) suggested poverty in rural areas and especially amongst SMFs has deteriorated over time. This high incidence of poverty is a matter of concern in view of the fact that poverty eradication has been one of the main millennium development goals.

Banerjee et al., (2002) identified the Punjab, once a grain bowl of India, particularly affected state in the country along with Kerala, Andhra Pradesh and Assam, with a serious level of poverty and hunger. Overall, India has achieved growth (Ashraf, 2020) nonetheless at the same time economic inequalities have grown in India too (Manzoor, 2019; Sen and Himanshu, 2005). This is evidenced from the upward trajectory of consumption level over the last three decades, including amongst those in the top $20 \%$ of the rural population (Chancel and Piketty, 2017; Himanshu and Murgai, 2018), yet the bottom $80 \%$ of the rural population remains relatively poor. This illustrates the income/distribution disparity among rich and poor, urban and rural India. However, the sources, nature and consequences of poverty are diverse and multi-dimensional and demand a multi-prolonged approach as the majority of agricultural production takes place in the rural areas where, the level and incidence of poverty are most pronounced. This study estimates the trend, structure and determinants of poverty (level of income, the extent and nature of poverty and indebtedness) amongst rural households and SMFs.

\section{Land Fragmentation}

Agriculture performance disparity across regions in India and the factors influencing it, has been a subject of debate among academic researchers and policy makers 
(Mamgain, 2019). Researchers such as Birthal et al. (2014) and Bhalla and Singh (2012) identified the differences in the speed and pattern of technological change, institutional setting and environmental conditions, as the factors causing uneven agricultural growth. By contrast, Banerjee and lyer (2005) blamed the property right regime, created during the colonial period, for the variable pace and pattern of agricultural growth in post-independence India. Population growth and cultural systems as well as partible inheritance, have facilitated land fragmentation (supplyside cause, McPherson, 1982) and this is further exacerbated by a lack of support from credit providers (Sinha and Kumar, 2010). Small land holdings become unviable because small farms lack economies of scale and are unable to exploit technology usage. Consequently, this serves to 'push' farmers to seek employment in larger urban areas.

Poverty gives rise to social and legal implications (Foster and Rosenzweig, 2010). Figure 1.1 demonstrates the land fragmentation that depicts how fragmentation leads to sub-optimal outcomes, land is distributed amongst the next of kin. Consequently, the costs exceed the benefits whilst in the case of land consolidation the benefits exceed the costs, as is mostly the case in USA and the West. Land consolidation programmes failed due to the unwillingness of the landowners to participate because of the fear that they will be driven out of agriculture due to farm mechanization facilitated by land consolidation (Niroula and Thapa, 2005; 2007). Other impediments in conducting land consolidation as Singh (1987) cited in Niroula and Thapa, (2005) are a lack of scientific land records, corrupt bureaucracy, legal loopholes and a lack of technical skills on the part of officials (p. 366). 


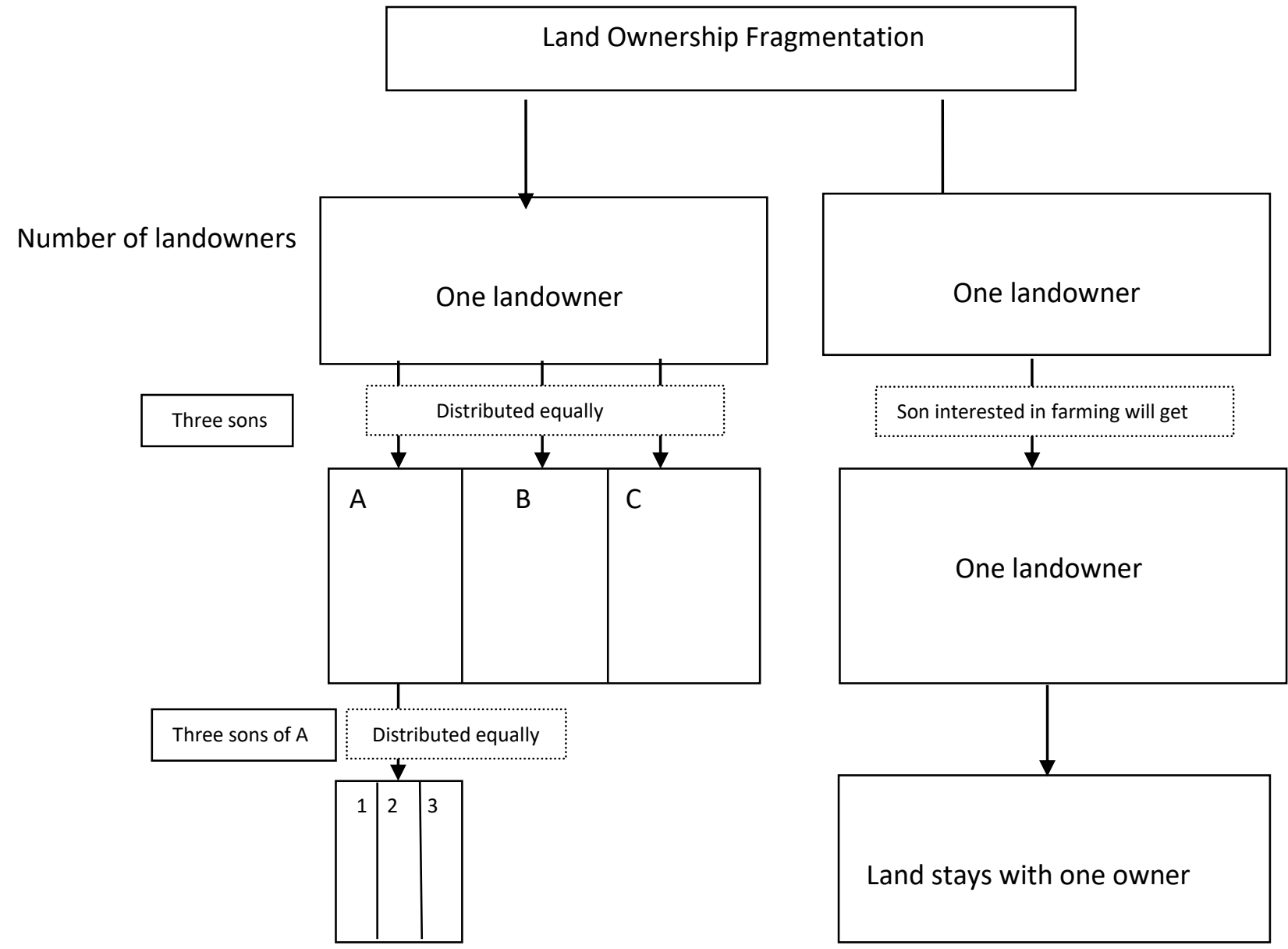

Figure 1.1: General representation of land fragmentation and consolidation

India is experiencing a decline in farm size from 1.57 hectares (ha) to 1.33 ha (Gol, 2015; Hazell et al., 2010) this is mainly due to inheritance law governing property (Ghatak and Roy, 2007) that continues to reduce agricultural land size unlike the USA and other Western countries. This suggests that it is imperative to address the issue and to make small and marginal landholdings more productive. There is a need to study the issues affecting marginal farmers in order to enhance their productivity and to mitigate the negative consequences relating to poverty.

\section{Context and methodology}


Entrepreneurial capability, access to finance and poverty in rural areas are inextricably connected (Adeniyi, 2019; Goyal, 2018; Sandhu et al., 2012:17). Poverty amongst SMFs gives rise to inequality and migration towards urban cities (Baldwin, 2018; Manzoor, 2019; Sandhu, 2007:2020). Therefore, the embedding of enterprise amongst small farmers, is a desirable research objective.

\section{Data collection and Sample}

A mixed methods approach was used to collate, cross-tabulate and analyse the data captured during the in-depth, face-to-face interviews based on a semistructured questionnaire carried out in July 2017 with a usable sample of 185 farmers, out of 250 approached, from the state of the Punjab in India. This method is supported by experts such as Newman (2000) and O'Hare (2020), who advocate using a face-to-face interview format instead of a self-administered questionnaire to obtain reliable data, especially SMFs are unable to read and write or provide structured answers in a written format. The questionnaire was piloted with groups of farmers and the revised questionnaire was distributed among entrepreneur farmers (McElwee, 2008; McElwee, and Bosworth, 2010). To make the questionnaires accessible, either the researcher herself or the interpreter carried out the interviews. Table 1 classifies the sample into five groups according to the size of land holding, landless, (not owning /possessing any land), marginal farmers (up to 1 acre of land), small farmers (1-2 acres of land), medium farmers (2-4 acres of land) and large farmers (10 acres and above).

The location of the fieldwork is the Punjab, North India as depicted in Figure 1 , with an area of 50,362 square kilometres, population of $29,673,462$, of which 66 per cent are located in the rural areas (Population of India, 2016). The 5 selected districts (Gurdaspur, Jalandhar, Amritsar, Patiala and Nawanshahr) of the state of Punjab, highlighted in Figure 1.2, have unique socio-demographic and geographical characteristics. The Gurdaspur, Amritsar and Patiala districts have a high density of small and mid-sized farms whereas Jalandhar and Nawanshahr have medium and large sized farms. Table 1 provides statistics for the different categories of farmers who took part in the study. Participants were identified through a purposive sampling technique and interviews were taped and transcribed. The interviews were coded 
and analysed with NVivo, to assist in identifying and mapping patterns from the qualitative data and quantitative data was used to carry out a numerical analysis.

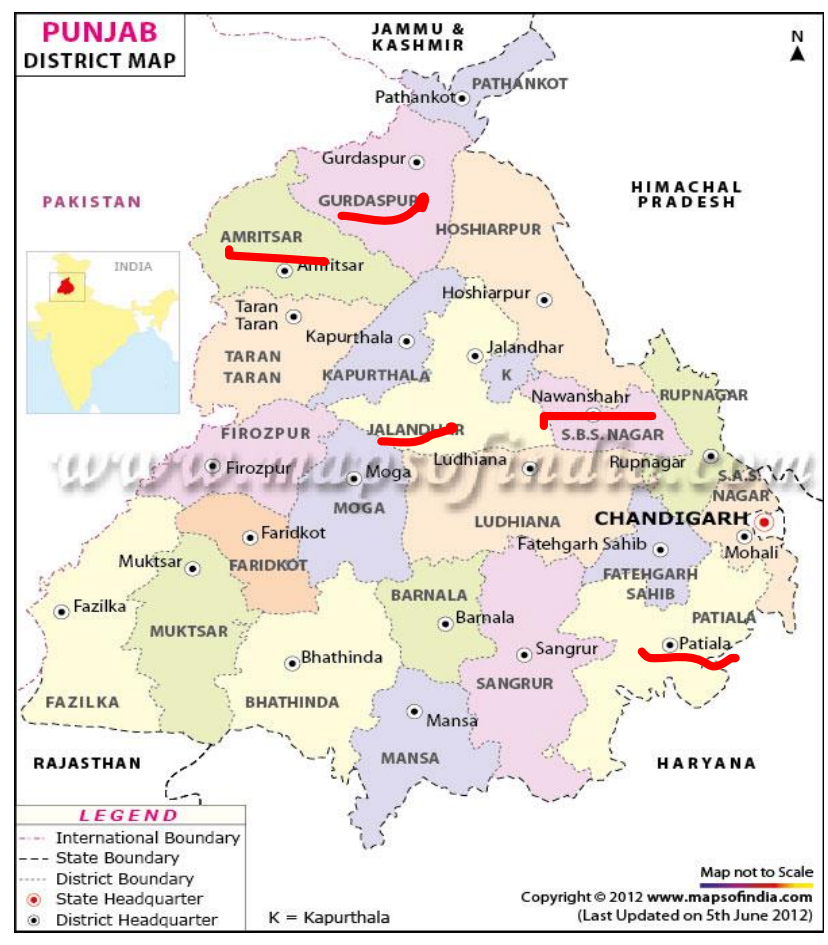

Figure 1.2: Map of Indian Punjab

\section{INSERT TABLE 1 HERE}

Poverty measurement criteria:

A household was classified as poor if its per capita per day income is less than $\$ 1.90$ based on the World Bank Criterion and the income was estimated using purchasing power parity (PPP) between the USD (US dollar) and the Indian Currency (Rupees), where $1 \mathrm{USD}=\mathrm{Rs} 14.67$ (Singh et al., 2012). In the most recent literature on the incidence of poverty, the World Bank (2016:2019) suggested two measures. Following the World Bank's methodology (Gol, 2011) $\$ 1.90$ per day is used as the poverty measurement criteria for this study: Annual per capita income $=$ Rs. 18,418.95 per annum, per person.

The Empirical model: 
The multiple regression model is used to analyse the factors, which explain and influence poverty amongst small farmers. The multiple regression model used is:

$$
Y=a x_{1} b^{1} . x_{2} b^{2} \ldots \ldots x_{n}{ }^{b n}
$$

Where, $\mathrm{Y}$ is the dependent variable, $\mathrm{X}_{1}$ through $\mathrm{X}_{\mathrm{n}}$ are explanatory variables, ' $a$ ' is the constant term and $b^{1}$ through $b^{n}$ are the regression coefficients for $x_{1}$ through $\mathrm{x}_{\mathrm{n}}$, respectively.

\section{Determinants of Income-based Poverty: Category-wise}

Based on well-recognised criteria, poverty is measured in terms of per capita income or per capita consumption. Therefore, the factors that affect the per capita income or per capita consumption expenditure of the marginal and small farm-size categories are considered to be the determinants of poverty. The variables used to capture the relationship are:

$$
Y=f\left(x_{1}, x_{2}, x_{3}, x_{4}, x_{5},\right)
$$

Where, $Y=$ Per capita income (Rs.)

$\mathrm{X}_{1}=$ family-size (number)

$\mathrm{X}_{2}=$ Per capita income from subsidiary occupations (Rs.)

$\mathrm{X}_{3}=$ Per capita expenditure on education

$\mathrm{X}_{4}=$ No. of earners

$\mathrm{X}_{5}=\mathrm{Land} /$ Farm-size (acres)

The regression model attempts to explain the variations in per capita income of the marginal and small farmers in the rural Punjab. Variations in the per capita income of the marginal and small farmers are explained by family-size, income from subsidiary occupations, expenditure on education, number of earners and farm-size.

\section{Results}

\section{Preliminary Results}

The results reported in Table 2 exhibit the extent of poverty in the selected agricultural households. Poverty incidences were high among the small farmers (64 per cent) and marginal farmers (80 per cent). Furthermore, female-headed households experienced higher levels of poverty than their male counterparts. These findings are opposite to those of Ogwumike and Akkinnibosun (2013), who reported for Nigeria. This variation could be attributable to the fact that male farmers are 
involved in many other occupations besides farming whereas women in rural areas have limited skills and limited scope to seek external jobs. This disadvantage is further exacerbated due to cost and class discrimination. Moreover, the limited access to finance and lack of collateral make female farmers less bankable, consequently, they are unable to increase the agricultural productivity, which limits their entrepreneurial engagement. In India, this poses a special challenge because women play a larger role in agriculture than men especially within small land holdings (Sandhu et al., 2012; 2017; Sandhu, 2020).

\section{INSERT TABLE 2 HERE}

To promote entrepreneurial talents amongst female entrepreneurs' conscious efforts need to be made to educate and provide credit facilities for female farmers. As reported in table 2, poverty incidence is higher in farmers' households with family members aged between 20-30 and above 60. There is an inverse relationship between the informal lenders and poverty levels, exhibiting a vicious cycle of debt and the respondents felt trapped as one of the marginal farmer respondents articulated:

"Setting-up an alternative business requires money, bank need collateral and we do not have enough land or other assets to pledge. Therefore, we have to rely on informal lenders to buy our crops and keep all money, leaving us with nothing educate children or even buy medicine."

In addition, now large farmers are also facing the problem of land fragmentation. They have also reported their concern about land fragmentation as their family sizes grow. Congruently, there is an observed trend that wealthy farmers are keen to send some of their children abroad. One respondent showed concern that "I am really worried about my grandchildren what they will do in life, who are just going to get small parcels of land." 
Instead of developing enterprises, there was an observable trend amongst the youth from the Jat (cast) community to migrate abroad, this is trend is noted amongst SMFs. However, $90 \%$ of landowners do not want to sell their land. One respondent stated "One of my son want to sell his share of land and go to Canada to get a better life. But he does not understand Jats are recognised by their land holdings, it is their pride." There was also an unwillingness amongst farmers to consolidate or lease out their lands, 95 per cent answered 'no' to selling and leasing. Although 5 per cent were ready to lease. However, there was a common fear that they would lose out due to the corruption and various malpractices prevalent in India and a lack of laws that protect owners. This is a particular fear amongst owners living abroad. Adopting entrepreneurial practices and taking risk are hindered due to poor legal protection and due to various socio-cultural and socio-economic reasons (Niroula and Thapa, 2005; Sandhu, 2020).

\section{Determinants of Income based Poverty}

Tables $3 \& 4$, illustrate the number of farmers living below the poverty line of $\$ 1.25$ per day. Within the sample, 52 out of 65 small and marginal farmers live below the poverty line. However, the independent percentages of the marginal and small farmers are 100 per cent (29 out of 29) for marginal and 64 per cent (23 out of 36 ) for small farmers respectively. Thus, this $\$ 1.25 /$ day or Rs. 18,418.95/annum measure establishes an inverse relationship between the land/farm size and the farmers' population living below the poverty line. These findings are consistent with the guidelines by the Tendulkar committee, which state that a minimum of $0.8 \mathrm{ha}$ of farm size is needed to keep an agricultural family above the poverty line. 62 per cent of farmers in India own less than 0.80ha of cultivable land (Chand et al., 2011) and this figure continues to increase further with the ongoing division of landholdings. Close examination of the consequences of the division of land suggests that 36 percent poverty increase in the presence of poverty, which affects farmers' entrepreneurial initiatives to raise land yield, consequently have implications on their living standards.

23 percent of farmers recognised the importance of exit from poverty and the retaining of land lies with innovative entrepreneurial initiatives such as agritourism. Agritourism proved very successful in European countries such as Italy, and it is 
gaining popularity in North America and other countries (Carpio, et al., 2008). Arya and Akhtar (2019) suggested that to enhance the survival and income of marginal farmers, integrated farming may be the solution. However, marginal farmers suggested that they lack the skills and education to embrace Agritourism. However, when the respondents were asked about diversification and entrepreneurial means to increase income level, they either sometimes seemed to lack clarity as to how this could be achieved. When asked if they had ever considered crop diversification, 30 per cent of small and marginal farmers dismissed the idea, suggesting that their knowledge of the benefit of other enterprises or within farming was limited or nonexistent, one respondent explained, "We don't have enough land to experiment. Moreover, we have to buy wheat and rice to feed our families."

\section{INSERT TABLE 3 HERE}

\section{INSERT TABLE 4 HERE}

The regression analysis, reported in table 5, suggests that all the variables such as family-size, income from subsidiary occupations, expenditure on education, number of earners and farm/land size are statistically significant. The findings exhibit that income from farming activities is inversely related to the poverty status of the household. This shows that as the income from farming activities increases, the probability of being poor decreases. These findings support and justify that land fragmentation is leading to poverty amongst the farming households. To arrest the poverty, small farmers need to enhance productivity and develop entrepreneurial initiatives to raise income level.

\section{INSERT TABLE 5 HERE}

The findings show that family-size impacts on the living standards of SMFs. The regression coefficient for this variable is negative and significant. The larger the family, the greater the consumption needs and thus, the higher the poverty status of the household. However, to an extent a larger household size also augments the 
total labour supply of the farming household thereby enhancing its incomegenerating potential, so the effect of larger household size on poverty may be neutralized. The regression coefficient for income from subsidiary occupations is significant at 1 per cent level of probability. This suggests that farmers supplement their income through secondary occupations in addition to working on their small farm-size. The supplementary income appears to have a more significant positive impact on the small households than on the marginal ones. In addition, the respondents in the survey, 43 percent, were reported to have secondary enterprises although the enterprises were related to the selling of produce from the farms. An activity that, according to the respondents, had significantly enabled them to support their children's education.

The regression coefficient for expenditure on education is significant, thereby expressing that an increase of 1 per cent in the expenditure on education will lead to an increase of 0.14 per cent income for the marginal farm-size households. Thus, education has a significant effect on poverty. With attainment of education amongst the farming households, the prospects of getting a better and remunerative job improve and amongst such groups, the presence of enterprise was observed to be higher. It is therefore imperative that education should receive a high priority if poverty is to be reduced. Furthermore, the regression coefficient for the number of earning members and farm-size is positive and statistically significant; suggesting that households with more earning members are financially better off than the households with less earning members. Therefore, promoting entrepreneurial education and opportunities creates more job opportunities in and out of agriculture that also mitigates the effects of poverty.

The findings reported in table 5, suggest that the age of the farmers impacts on their financial positioning as well as on poverty levels amongst small farmers. It has been found that the poverty rate increases as the farmers move from the age group 20-29 to 30-39, and then decreases for ages 40 years to 60 for medium and large farmers. This could be attributed to farmers' land ownership rights, the financial deepening and shallowing that depicts such a relationship. This could be because at the early stage of life there is a greater energy and motivation to succeed. However, as the 
head of the family gets older, this energy begins to decline which increases the chances of the farmers' households falling into poverty.

\section{Discussion}

The purpose of the present study was to examine the mediating role of both access to finance and entrepreneurial education for SMFs in the Indian northern state of the Punjab. Further, it examines the inter-mediatory role of entrepreneurs and access to finance in the promotion of innovation, development and consequently poverty alleviation.

In doing so, the paper acknowledges the importance of an entrepreneurial mind-set to alleviate poverty amongst farming households. In this study, a scrutiny of the empirical analysis reveals that due to land fragmentation, the size of small landholdings progressively decreases and eventually makes farming non-viable for SMFs even though they use various mechanisms to improve agricultural productivity, through diversifying their farming operations, lowering farming costs and expanding the size of their farming operations. However, a lack of finance, entrepreneurial education, skills and inhibits farming operations. Despite their willingness and positive psychological capital (attitude), SMFs are unable to take on-farm expansion initiatives, which consequently has a major impact on their income and living standards. The findings exhibit that income from farming activities is inversely related to the poverty status of the household. Nevertheless, household income can positively influence farmers' willingness to expand (Cele and Wale, 2020; Jensen et al, 2015; Sandhu, 2020; Wang et al., 2020). This shows that as the income from farming activities increases, the probability of exiting poverty increases. These findings support and justify the view that land fragmentation is leading to poverty amongst the farming households. The findings suggest that SMFs are divested from enterprise due to their financial exclusion, a lack of access to education and large families' sizes in comparison to large farmers' situations. However, cultural and financial realities mean large farmers are also facing the problem of land fragmentation as family numbers grow and land is divided to provide an inheritance to all. These findings serve to extend the debate away from big quantitative studies and suggest that there is a need to undertake specific research on SMFs' emerging 
challenges to fill a specific gap within research, which has been missing in agricultural economics literature.

The results demonstrates inverse relationship between poverty and SMFs' entrepreneurial initiatives. It has been found that poverty is more visible in young and older households. Young and educated, tended to leave the rural areas to work in cities. Whereas individuals with less education and in debt tend to stay behind to work on farms. Moreover, the findings of this study suggest that the younger population often do not want to engage in farming activities, as they do not see it as rewarding, results consistent with Cele and Wale's (2020) research conducted in the Nigerian context. To raise the status and income of SMEs, agritourism and other farms of diversification can help, provided the government address the structural issues (such as adequate security arrangements and infrastructures) for the hosts and the guests, as raised by the respondents in this study. These results support the resource based view of previous studies that reported that entrepreneurship, innovation and productivity amongst farmers is dependent on farm size, land quality, labour, capital and farmers' skills and knowledge (Barbieri and Mshenga, 2008; Das and Patnaik, 2020; Phelan and Sharpley, 2012; Sandhu et al., 2012b; Sandhu, 2020).

\section{Conclusions}

The main premise of the paper is to promote entrepreneurial acumen and a desire to address the causes and consequences of poverty amongst SMFs. Enhancing entrepreneurial traits amongst small farmers could equip them to address the shortcomings arising from the diminishing returns from falling yield from small land holdings. The conclusions drawn from the study reveal that the income generated from the farming activities of the SMFs is insufficient to satisfy their needs. Therefore, measures to reduce poverty among SMFs should be aimed at improving the fertility of the land, providing a basic infrastructure to the poor in rural areas, enhancing access to credit and providing farmers with entrepreneurial education. Thus, uplifting their living standards by introducing innovation in farming practices and to embed entrepreneurial actions to augment income levels. Furthermore, a positive relationship between farm-size and farm business income suggests that 
there is a strong case for land reforms in favour of the marginal and small farmers that will ensure optimal land holdings are maintained for their economic viability. There are examples in the literature where land reforms enhanced agricultural productivity in some of the states of India such as West Bengal, Kerala and recently Tripura and Karnataka (Banerjee et al., 2002; Lele et al., 2018). Under the tenancy reform in West Bengal, an estimated $1.6 \mathrm{~m}$ tenants were registered and given heritable rights over tenanted land (Bandyopadhyay, 2003; Dasgupta, 2004). This suggests the government may reform financial institutions to improve access to finance, improve the functioning and lending procedure of the commercial banks and to strengthen the functioning of co-operative banks. Entrepreneurial education amongst the SMFs will serve to increase employment creation opportunities and lead to the establishment of balanced farming enterprises. The findings suggest that there is a need for empirically rigorous, longitudinal research to measure the impact of supporting small and marginal farmers through improved access to finance, providing adequate land holdings and entrepreneurial education in order to mitigate the effects of poverty.

\section{References}

Adeniyi, D. (2019), "Sustainable irrigation agriculture for food security and poverty reduction among smallholder farmers in Northern Nigeria", Unpublished PhD Thesis submitted University of the Western Cape.

Alsos, G. and Carter, S. (2006), "Multiple business ownership in the Norwegian farm sector: Resource transfer and performance consequences”, Journal of Rural Studies, Vol. 22 No.3, pp.313-322.

Alsos, G. Carter, S. and Ljunggren, E. eds., (2011), The handbook of research on entrepreneurship in agriculture and rural development. Edward Elgar Publishing, Cheltenham, UK.

Alsos, G. Carter, S. and Ljunggren, E. (2014), Entrepreneurial families and households. The Routledge Companion for Entrepreneurship. Routledge, London, pp.165-178.

Ansari, I. and Akhtar, S. (2012), "Incidence of poverty in India: issues and challenges", International Journal of Multidisciplinary Research, Vol. 2 No. 3, pp. 443-449.

Arya, P. and Akhtar, J. (2019), "Impact of climate change on sustainable food grains production in Uttar Pradesh", European Journal of Business and Social Sciences, Vol. 7 No. 2, pp.76-89.

Asante, B. Wiredu, A. Martey, E. Sarpong, D. and Mensah-Bonsu, A. (2014), "NERICA adoption and impacts on technical efficiency of rice producing households in Ghana: implications for research and development", Journal of Experimental Agriculture International, Vol.1 No. 1, pp.244-262.

Ashraf, F. (2020), "Strategic intervention for poverty elimination: a study of rural India", Studies in Indian Place Names, Vol. 40 No.12, pp.16-33. 
Awunyo-Vitor, D. (2018), "Theoretical and conceptual framework of access to financial services by farmers in emerging economies: implication for empirical analysis", Acta Universitatis Sapientiae, Economics and Business, Vol. 6 No.1, pp.43-59.

Baldwin, S. (2018), Poverty and politics: The rise and decline of the farm security administration. UNC (the University of North Carolina) Press Books, USA.

Barbieri, C. and Mshenga, P. (2008), "The role of the firm and owner characteristics on the performance of agritourism farms", Sociologia Ruralis, Vol. 48 No. 2, pp.166-183.

Bashir, T. Khan, A. Behera, S. and Gautam, P. (2010), "Socio-economic factors threatening the survival of Ganges River Dolphin Platanista gangetica gangetica in the upper Ganges River, India", Journal of Threatened Taxa, Vol. 2 No. 8, pp.1087-1091.

Bateman, D. and Ray, C. (1994), "Farm pluriactivity and rural policy: Some evidence from Wales1", Journal of Rural Studies, Vol. 10 No. 1, pp.1-13.

Bandyopadhyay, D. (2003), "Land reforms and agriculture: The West Bengal experience", Economic and Political Review, Vol. 38 No. 9, pp.879-84.

Banerjee, A. Gartler, V. Paul, J. and Ghatak, M. (2002), "Empowerment and efficiency: tenancy reform in West Bengal", Journal of Political Economy, Vol. 110 No. 2, pp. 239-280.

Banerjee, A. and lyer, G. (2005), "History, Institutions and Economic Performance, the Legacy of the Colonial Land Tenure Systems in India", The American Economic Review, Vol. 95 No. 4, pp. 11901213.

Bee, F. (2007), Rural financial markets in Tanzania: An analysis of access to financial services in Babati district, Manyara Region. PhD thesis submitted at the University of South Africa.

Bhalla, G. and Singh, G. (2012), Economic Liberalization and Indian Agriculture: A District-level Study, Sage Publications India Private Limited, New Delhi.

Bharti, R. and Sagar, M. (2020), "Production performance of backyard poultry reared by rural women in Budelkhand region of Uttar Pradesh." Available at: http://www.thepharmajournal.com/archives/2020/vol9issue3/PartA/9-1-42-575.pdf (Accessed 13th June 2020)

Birthal, S. Joshi, K. Negi, S. Agarwal, S. (2014), "Changing sources of growth in Indian agriculture: implications for regional priorities for accelerating agricultural growth", Discussion paper 01325, International Food Policy Research Institute, Washington DC, USA.

Bruinsma, J. (2017), World agriculture: towards 2015/2030: an FAO study. Routledge, New York.

Bryden, J. and Geisler, C. (2007), "Community-based land reform: lessons from Scotland", Land Use Policy, Vol. 24 No. 1, pp.24-34.

Chancel, I. and Piketty, T. (2017), "Indian income inequality, 1922-2015: from british raj to billionaire raj?' WID. World Working Paper Series 2017/11, Paris: World Inequality Lab, Available at: https://wid.world/document/chancelpiketty2017widworld (Accessed 16th July 2017)

Chand, R. Prasanna, P. and Singh, A. (2011), "Farm size and productivity: understanding the strengths of smallholders and improving their livelihoods", Economic and Political Weekly, Vol. XLVI Nos.26 \& 27, pp.5-11.

Chavan, P. and Sivamurugan, T. (2017), Formal credit and small farmers in India. In: Swaminathan, M., and Bakshi, S., Editors, How to Small Farmers Fare?, Tulika Books, New Delhi, pp.1-40.

Carpio, C. Wohlgenant, M. and Boonsaeng, T. (2008), "The demand for Agritourism in the United States", Journal of Agricultural and Resource Economics, Vol. 32 No. 2, pp. 254-269. 
Cele, L. and Wale, E. (2020), "Determinants of smallholders' entrepreneurial drive, willingness and ability to expand farming operations in KwaZulu-Natal", Development in Practice, Vol.1 No.1, pp.1-15.

Coelli, T. and Battese, G. (1996), "Identification of factors, which influence the technical inefficiency of Indian farmers", Australian Journal of Agricultural Economics, Vol. 40 No. 2, pp.103-128.

Das, A. and Patnaik, N. (2020), "Innovations in agricultural credit disbursement and payment systems for financial Inclusion in Rural India", International Journal of Current Microbiology and Applied Sciences, Vol. 9 No. 2, pp.11-18.

Dasgupta, A. (2004), "Agrarian reforms in West Bengal: a closer look at actual Facts", Unpublished thesis, Department of Economics, University of California, Riverside.

Dey, S. (2018), "The role of employment diversification in reducing vulnerability to poverty among marginal and smallholder agricultural households in India", Margin: The Journal of Applied Economic Research, Vol. 12 No. 1, pp.88-112.

Diao, X. McMillan, M. and Rodrik, D. (2019). The recent growth boom in developing economies: A structural-change perspective. In The Palgrave Handbook of Development Economics, Palgrave Macmillan, Cham, pp. 281-334.

Fitz-Koch, S. Nordqvist, M. Carter, S. and Hunter, E. (2018), "Entrepreneurship in the agricultural sector: A literature review and future research opportunities", Entrepreneurship Theory and Practice, Vol. 42 No. 1, pp.129-166.

Foster, A. and Rosenzweig, M. (2010), "Barriers to farm profitability in India: mechanization, scale and credit markets", In Conference Agriculture for Development-Revisited, University of California at Berkeley, October, Vol. 24 No. 1, pp. 1-2.

Ghatak, M. and Roy, S. (2007), "Land reform and agricultural productivity in India: a review of the evidence", Oxford Review of Economic Policy, Vol. 23 No. 2, pp. 251-269.

Ghuman, R. (2001), "WTO and Indian agriculture: crisis and challenges: a case study of Punjab", Man and Development, Vol. 23 No. 2, pp 67-98.

Ghuman, R. (2008), "Socio-economic crisis in rural Punjab", Economic and Political Weekly, Vol. 43 No. 6, pp. 12-15.

Government of India (Gol). (2011), "Census of India", Available at: http:// www.censusindia.net (accessed 20 th June 2018).

Government of India (Gol). (2015),"Agricultural situation in India", Vol. 72 No. 3, pp. 35-36, Available at: http://eands.dacnet.nic.in/Publication12-12-2013/January 2015.pdf (accessed $3^{\text {rd }}$ March 2017).

Government of Punjab (GoP). (2010), "Statistical abstracts of Punjab", Government of Punjab. Available at: http:I|Punjabgovt.nic.in (accessed 11 th May 2017).

Goyal, A. (2018), "Major challenges and problems of rural entrepreneurship in India", ACUMEN. Available at: http://www.daimsr.in/pdf/acumen 2018.pdf\#page=9 (accessed 10

Harriss-White, B. (2005), "Destitution and the poverty of its politics- with special reference to South Asia", World Development, Vol.33 No.6, pp. 881-892.

Harriss-White, B. (2006), "Poverty and capitalism”, Economic and Political Weekly, Vol. 41 No. 13, pp. 1241-1246.

Hazell, P. Poulton, C. Wiggins, S. and Dorward, A. (2010), "The future of small farms: trajectories and policy priorities", World Development, Vol. 38 No.10, pp. 1349-1361.

Hendrickson, M. Howard, P. and Constance, D. (2017), "Power, food and agriculture: implications for farmers, consumers and communities", Consumers and Communities (November 1, 2017). Available 
on:

https://www.econstor.eu/bitstream/10419/171171/1/20171101 hendrickson howard constance pow er food and agriculture.pdf (accessed 26th November 2018).

Hickey, S. du Toit, A. (2013), "Adverse incorporation, social exclusion and chronic poverty, chronic poverty", In: Shepherd, A., and Brunt, J., Editors, Chronic Poverty. Rethinking International Development Series, Palgrave Macmillan, London, pp. 134-159.

Himanshu and Murgai, R. (2018), "Inequality in India: a review of levels and trends", Mimeo. Washington, DC and Delhi: World Bank and JNU University.

Hinrichs, C. Gillespie, G. and Feenstra, G. (2004), "Social innovation and learning at retail farmers' markets", Rural Sociology, Vol. 69 No. 1, pp.31-58.

Hoff, K. and Stiglitz, J. (1997), "Moneylenders and bankers: price-increasing subsidies in a monopolistically competitive market", Journal of Development Economics, Vol. 52 No.2, pp. 429-462.

ljaz, A. Siddiqui, S. Rasheed, R. and Nawaz, M. (2019), "Factors affecting delay in agricultural loan recovery among small scale farmers in Sahiwal region in Pakistan", Journal of Management Sciences, Vol. 6 No. 2, pp. 48-53.

Igwe, P. Rahman, M. Odunukan, K. Ochinanwata, N. Egbo, O. and Ochinanwata, C. (2020), "Drivers of diversification and pluriactivity among smallholder farmers- evidence from Nigeria", Green Finance, Vol. 2 No. 3, pp.263-283.

Jelsma, I. Woittiez, L. Ollivier, J. and Dharmawan, A. (2019), "Do wealthy farmers implement better agricultural practices? An assessment of implementation of good agricultural practices among different types of independent oil palm smallholders in Riau, Indonesia", Agricultural Systems, Vol. 170 No. 1, pp.63-76.

Jensen, K. Lambert, D. Clark, C. Holt, C. English, B. Larson, J. Yu, T. and Hellwinckel, C. (2015), "Cattle producers' willingness to adopt or expand prescribed grazing in the United States", Journal of Agricultural and Applied Economics, Vol. 47 No. 2, pp.213-242.

Kohli, D. and Singh, N. (2005), "The green revolution in Punjab, India: the economics of technological change", Journal of Punjab Studies, Vol. 12 No. 2, pp. 285-306.

Krishna, A. (2004), "Escaping poverty and becoming poor: who gains, who loses, and why?", World Development, Vol. 32 No. 1, pp. 121-136.

Krishna, A. Kapila, M. Porwal, M. and Singh, V. (2005), "Why growth is not enough: household poverty dynamics in Northeast Gujarat, India", Journal of Development Studies, Vol. 41 No. 7, pp. 1163-1192.

Krishna, A. (2006), "Pathways out of and into poverty in 36 villages of Andhra Pradesh, India", World Development, Vol. 34 No. 2, pp.271-288.

Kumari, V. and Singh, R. (2009), "Fragile human capital causes poverty in North Bihar: empirical evidences", Agricultural Economics Research Review, Vol. 22 No.1, pp. 99-108.

Lele, U., Agarwal, M. and Goswami, S. (2018), Patterns of structural transformation and agricultural productivity growth, Rajas Parchure Gokhale Institute of Politics and Economics, Pune.

Mamgain, R. (2019), Formal labour market in urban India: job search, hiring practices and discrimination. SAGE Publications, India.

Manzoor, S. (2019), "Poverty reduction programmes in Jammu and Kashmir", Economic \& Social Dimensions, Book Bazooka Publication: India, Kanpur, p. 231.

Martey, E. Wiredu, A. Etwire, P. and Kuwornu, J., (2015), "Impact of credit on technical efficiency of maize producing households in Northern Ghana," In Selected Paper presented at the Centre for the 
Study of African Economies (CSAE) Conference, March, pp. 22-24. Available at: https://www.researchgate.net/profile/Edward Martey/publication/274565052 Impact of Credit on T echnical Efficiency of Maize Producing Households in Northern Ghana/links/55228bce0cf2f9c13 052e0f5/Impact-of-Credit-on-Technical-Efficiency-of-Maize-Producing-Households-in-NorthernGhana.pdf (accessed $1^{\text {st }}$ March 2019).

Matlay, H. Rae, D. Solesvik, M. Westhead, P. and Kolvereid, L. (2012), "Student intentions to become self-employed: the Ukrainian context", Journal of Small Business and Enterprise Development, Vol. 19 No. 3, pp.441-460.

McElwee, G. (2008), "A taxonomy of entrepreneurial farmers", International Journal of Entrepreneurship and Small Business, Vol. 6 No. 3, pp. 465-478.

McElwee, G. and Bosworth, G. (2010), "Exploring the Strategic Skills of Farmers across a Typology of Farm Diversification Approaches”, Journal of Farm Management, Vol. 13 No. 12, pp. 819-838.

McPherson, M. (1982), "Land fragmentation: a selected literature review", Development Discussion Paper No. 141. Harvard Institute for International Development, Harvard University, pp. 4-8.

Meher, S. (2015), "Innovations and exclusion in agriculture: are small farmers benefitting from agricultural innovation and growth in India?", International Journal of Social Science and Development Policy, Vol. 1 No. 1, pp. 63-75.

Moreno-Pérez, O. (2015), "Extended farm family arrangements: What statistics do not say about agricultural structure?", Available on: $\quad$ https://www.sfer.asso.fr/source/coll-structuresagricoles2015/sa2015-c1-moreno.pdf (Accessed on 15th December 2018).

Mosse, D.( 2007), "Power and Durability of Poverty: A Critical Exploration of the Links between Culture, Marginality and Chronic Poverty", Chronic Poverty Research Centre Working Paper, 107, Institute for Development Policy and Management, School of Environment and Development, University of Manchester.

Murgai, R. Ali, M. Byerlee, D. (2001)," Productivity Growth and Sustainability in Post-Green Revolution Agriculture: The Case of the Indian and Pakistan Punjabs", The World Bank Research Observer, Vol. 16 No. 2, pp. 199.

Niroula, G. and Thapa, G. (2005), "Impacts and causes of land fragmentation and lessons learned from land consolidation in South Asia", Land Use Policy, Vol. 22 No. 4, pp. 358-372.

Niroula, G. and Thapa, G. (2007), "Impacts and causes of land fragmentation on input use, crop yield and production efficiency in the mountains of Nepal", Land Degradation and Development, Vol. 18 No. 3, pp. 237-248.

Ogwumike, F. and Akkinnibosun, M. (2013), "Determinants of poverty among farming households in Nigeria", Mediterranean Journal of Social Sciences, Vol. 4 No. 2, pp. 365-373.

O'Hare, T. (2020), Evidence-based practices for social workers: An interdisciplinary approach. Oxford University Press, USA.

Olubiyo S. (2003), "Beyond the risk factor: bank lending to small-scale peasant farms in Nigeria", Journal of African Review of Money Banking and Finance, Vol. 1 No. 1, pp.5-22. Available at: http://www.jstor.org/stable/23026310 (accessed $4^{\text {th }}$ January 2010).

Patel, U. (2004), Role of State-Owned Financial Institutions in India: Should the Government "Do" or "Lead"? In: Conference on 'Role of State- Owned Financial Institutions' Washington, D.C., April 26-27. Available at: http://info.worldbank.org/etools/docs/library/156393/stateowned2004/pdf/Patel RoleSOBsIndiaFINAL.pdf

Phelan, C. and Sharpley, R. (2012), "Exploring entrepreneurial skills and competencies in farm tourism", Local Economy, Vol. 27 No. 2, pp.103-118. 
Population of India (Pol). (2016), “India's population in 2016", Available at http://www.indiaonlinepages.com/population/india-current-population.html (accessed on $11^{\text {th }}$ January 2018).

Rajiv, M. Vani, B. and Bhattacharjee, M. (2012), "Nature and dimensions of farmers' indebtedness in India", Available from: http://www.ifrogs.org/PDF/WP-2016-005.pdf (accessed on $7^{\text {th }}$ January 2018).

Rangarajan, C. (2014), "Rangarajan report on poverty", Available at: https://pib.gov.in/newsite/printrelease.aspx?relid=108291 (accessed on 17 th July 2016).

Sandhu, N. (2007), "An empirical investigation of financial institutions' lending policies towards agribusiness during the post-green revolution in Punjab, India", Unpublished PhD thesis, Birmingham City University.

Sandhu, N., (2020), "Dynamics of banks' lending practices to farmers in India. Journal of Small Business and Enterprise Development. Available from: https://www.emerald.com/insight/content/doi/10.1108/JSBED-05-2019-0161/full/html (Accessed on 28th October 2020).

Sandhu, N. Hussain, J. and Matlay, H. (2012a), "Barriers to Finance Experienced by Female Owner/managers in India", Journal of Small Business and Enterprise Development, Vol. 19 No. 4, pp.640-655.

Sandhu, N. Hussain, J. and Matlay, H. (2012b), "Entrepreneurship education and training needs of family businesses operating in the agricultural sector of India", Education+ Training, Vol. 54 Nos.8/9, pp. 727-743.

Sandhu, N. Scott, J. Hussain, J. Gibb, J. Sinha, P. and Akoorie, M. (2017), "Exploring entrepreneurial finance and gender in an emergent entrepreneurial ecosystem: the case of the Punjab, northern India", Entrepreneurial Ecosystems and growth of Women's entrepreneurship. Edward Elgar: Cheltenham, pp.172-196.

Sen, A. (1964), "Size of holdings and productivity", Economic Weekly, Vol.16 No.1, pp.323-26.

Sen, A. and Himanshu, (2005), "Poverty and Inequality in India: Getting Closer to the Truth", Reprinted in Deaton, A., and Kozel, V., Editors. Data and Dogma: The Great Indian Poverty Debate. Macmillan, New Delhi.

Singh, N. (2010), "Rural Healthcare and Indebtedness in Punjab", Economic and Political Weekly, Vol. XLV No.11, pp. 22-25.

Singh, R. Kumar, P. and Woodhead, T. (2002), "Smallholder farmers in India: food security and agricultural policy", RAP Publication: 2002/03. Available from: http://www.fao.org/documents/show.cdr.asp?url_file=/DOCREP/005/AC484/AC484E00.htm (accessed1 $17^{\text {th }}$ April 2010).

Singh, K. Singh, R. Meena, M. Kumar, A. Jha, A. and Kumar, A. (2012) "Rural poverty in Jharkhand: an empirical exploration of socioeconomic determinants", MPRA (Munich Personal RePEc Archive) Paper No. 44811. Available from: http://mpra.ub.uni-muenchen.de/44811 (accessed 20 th July 2014).

Sinha, R. and Kumar, R. (2010), "Innovative technologies, institutions and policies for successful value chains for tur farmers: a case study of NCDEX spot", Agricultural Economics Research Review, Vol. 23 No.1, pp.427-436.

Srivastava, S. Chand, R. Singh, J. Kaur, A. Jain, R. Kingsley, I. and Raju, S. (2017), "Revisiting groundwater depletion and its implications on farm economics in Punjab, India", Current Science, Vol. 113 No. 3, pp. 422-429. 
Tilly, C. (2007), "Poverty and the Politics of Exclusion", In: Narayan, D., and Petesch, P., Editors, Moving out of Poverty: Cross Disciplinary Perspectives on Mobility. Palgrave Macmillan, Basingstoke, pp. 45-76.

Vatta, K. Garg, B. and Sidhu, M. (2008), "Rural employment and income: the inter-household variations in Punjab", Agricultural Economics Research Review, Vol. 21 No. 2, pp. 201-210.

Wang, J. Xin, L. and Wang, Y. (2020), "How farmers' non-agricultural employment affects rural land circulation in China?", Journal of Geographical Sciences, Vol. 30 No. 3, pp.378-400.

Welter, F. (2011), "Contextualizing entrepreneurship-conceptual challenges and way", Entrepreneurship Theory and Practice, Vol. 35 No. 1, 165-184.

Williams, G. Thampi, B. Narayana, D. Nandigama, S. and Bhattacharyya, D. (2012), "The politics of defining and alleviating poverty: state strategies and their Impacts in rural Kerala", Geoforum, Vol. 43 No. 1, pp. 991-1001.

Wongnaa, C. and Awunyo-Vitor, D. (2018), "Achieving sustainable development goals on no poverty and zero hunger: Does technical efficiency of Ghana's maize farmers matter?", Agriculture \& Food Security, Vol. 7 No. 1 , p.71.

World Bank, (2001), Finance for growth: policy choices in a volatile world, A World Bank Policy Research Report. World Bank, Washington D.C.

World Bank, (2004), Resuming Punjab's prosperity: opportunities and challenges ahead. World Bank, Washington D.C.

World Bank, (2008), World development report 2008: Agriculture for Development. World Bank, Washington D.C.

World Bank, (2016a), World Bank's poverty commission releases report on how to better measure and monitor global poverty. World Bank, Washington D.C.

World Bank, (2016b), Poverty and shared prosperity: taking on inequality. World Bank, Washington, DC.

World Bank, (2019), Measuring poverty. World Bank, Washington, DC.

Zahra, S., (2007), "Contextualizing theory building in entrepreneurship research", Journal of Business Venturing, Vol. 22 No. 3, pp.443-452.

Zhou, W., Yang, X., Li, Y. and Zhang, Y., (2019), "Pattern versus level: a new look at the personalityentrepreneurship relationship", International Journal of Entrepreneurial Behavior \& Research. Vol. 25 (1), pp.150-168. 